\title{
A HISTORIAN OF WORLD SOCIETY: A STUDY OF THE HISTORIAN ERIC HOBSBAWM AND A CRITIQUE OF HIS AGE OF CAPITAL
}

\author{
V. Dodoo \\ Department of History and Political Studies \\ Faculty of Social Sciences, \\ Kwame Nkrumah University of Science and Technology, \\ Kumasi, Ghana
}

\begin{abstract}
Professor Eric Hobsbawm may be described as a professional Marxist historian. The subjects he writes about include labour, artisans, peasants and the working class or, in short, the "forgotten majority" in the society. He regards himself as a historian of society and he practises dynamic history which is the interpretation of society with a view to changing it for the better. He has suggested that the pre-condition for history must be the existence of a total unit or system and has, accordingly, argued that world history - which he has undertaken in Age of Capital is only possible after 1848 when it became possible to think of the world as one unified economy.
\end{abstract}

Keywords: world history, world society, capital, working class

\section{INTRODUCTION}

This paper is not an attempt to do a biography of Eric John Hobsbawm. It is an effort to understand him as a historian. He has written extensively and I do not propose to look at all his works. I will limit myself to a few of them, especially, Age of Capital.

The paper is divided into two parts. In the first part, I will attempt to understand the thought of the man, since it is not possible to understand the historian without understanding the man who writes such history. In the second part, I will undertake a critique of Age of Capital with a view to finding out how it serves as a window into Hobsbawm's practice of history. There are seven sections. I - IV constitute part one while V - VII make up the second part. I is the introduction, II discuses his profession, III examines his approach to doing history while IV is a survey of his books. V begins the critique of Age of Capital, VI discusses the structure of the book and VII is the conclusion.

When confronted with the problem of finding a suitable theme for a symposium to be held in honour of Eric Hobsbawm at the time of his retirement as professor of Economic and Social History at Birkberk College, Pat Thane, Geoffrey Crossick and Roderick Floud decided on 
"Capitalism and Its Pre-Capitalist Heritage". In the opinion of these three, the dominant theme in all Hobsbawm's writings is the dialectical relationship between the two phenomena: “...what is revolutionarised or what is adapted or rejected from the older societies in the transition to full industrial capitalism; the process by which within certain limits, the pre-capitalist heritage shapes and informs economic, social, political and cultural change among all social groups and within the society as a whole (Thane et al., 1984).

Hobsbawm wrote about peasants, labour, the working class and about capital so, without question, this is an accurate assessment of him and undoubtedly, much of what will appear in this paper will go towards substantiating it. Nevertheless, I was not particularly satisfied to employ that theme for my take off. I wanted something more personal, a trait unique to the individual to predispose him to produce works with that theme. Fortunately, Hobsbawm himself supplied it. In the preface to volume I of History of Marxism, he quotes from Marx to serve as a guide for the construction of that history.

...the philosophers have hitherto only interpreted the world, the point, however, is to change it (Hobsbawm, 1982).

What is the use of explanation if it has no influence on the future of the society it seeks to explain? Theory without practice is empty and practice without a theoretical foundation is dead, the two are inseparable. This approach of studying society with the view to changing it for the better is made possible for historians by historical materialism and it is this methodology which animates the history which Hobsbawm writes. When the matter is put this way, it is easier to appreciate Hobsbawm's lack of sympathy for historians who engage in "superficial rationalisations" and "for whom the irrational or the providential is the only thing of consequence in the conception of the past". In an introduction to the maiden issue of Past and Present he (together with John Morris) condemns the method of Fisher in the following words:

... The view of H.A.L. Fisher that history is merely one damned thing after another is ... unwarrantable ... To believe with these writers and others that the pattern we find in the past is merely the subjective one we put into it from the present, is in effect, to deny that it can be scientific in any real sense (Hobsbawm and Morris, 1952).

For a scholar described as generally shy of polemics, such a punch, by any definition, cannot be said to be a soft one. However, in my view there is an explanation for this. The Marxist apparatus for studying history does not permit skirmishes with the issues studied. Rather it enables fundamental analysis and, depending on the orientation of the individual, it can permit a passionate identification with the subject of study. Hobsbawm writes about the culture of peasants, village artisans and labourers and Eugene Genovese points out that “... some of his angriest writings concern their oppression, the indignities to which they have been subjected [by industrial capitalism] and the courage and resourcefulness with which they have fought back (Thane et al., 1984). Thus while it is true that generally, he would avoid polemics, he would not remain silent over historians whose method amounts to acceptance of whatever happens as given, normal and final. This should explain his strong reaction to the publication of "The Stages Theses of Economic Growth" by W.W. Rostow's (Baran and Hobsbawm, 1961). Together with Baran, he gives Rostow a lecture on historical materialism:

The historical materialist considers human actions and motivations to be complex results of the dialectical interaction of biotic and social processes, the latter continually propelled by the dynamism of the forces and the relations of production as well as by the ideological evolutions deriving from them and influencing them in turn. 
In other words on the question of Marxist approach to the study of history, an apparatus which enables Hobsbawm to fight the battles for the non-privileged in the society, he will not negotiate.

Hobsbawm does not appreciate the Fabian type of gradualism for the realisation of society's goals. He would prefer to apply a catalyst "after interpretation of the world" to speed up the process of change. Hence his fascination with Engel's prediction of the rebirth of socialism in England quoted in Labour's Turning Point: ...

It [i.e., cessation of English domination of the Atlantic staples trade] will do one great thing; it will break the last link which still binds the English working-class to the English middle class. This link was their common working of a national monopoly. That monopoly once destroyed, the British working-class will be compelled to take in hand its own interest, its own salvation, and to make an end of the wages system. Let us hope it will not wait until then (Hobsbawm, 1984).

\section{II: HIS PROFESSION}

Hobsbawm has written extensively. In 1948 his firs book, Labour's Turning Point, came out to be followed in 1959 by Primitive Rebels. During the next decade, he produced six books: $\underline{\text { Age }}$ of Revolution (1962), Labouring Men (1964),

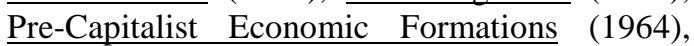
Industry and Empire (1968), Bandits (1969) and together with George Rude, Captain Swing in 1969. In 1973 he published Revolutionaries which is, in effect, a series of articles and reviews he had published elsewhere. The following year The Age of Capital came out to be followed five years later by The Forward March of Labour Halted. Another major work is the History of Marxism, the first volume of which he edited and published in 1982. His articles, reviews, contributions, comments etc. are too numerous to be listed here (Samuel, 1982). Let us simply say that he has published in most reputa- ble journals which deal with his subject around the world. Apart from Economic History Review (London) and Past and Present (London) where he was a regular contributor, he has published in Kyklos (Geneva), Monthly Review (New York), History and Theory (New York), Anarchi e Anarchia nel Mondo Contemporaneo (Turin) among others. In 1982 when he retired as professor of Economic and Social History at the Birkbeck College, two symposia were held in his honour. The papers presented at these symposia were subsequently published as: Pat Thane, Geoffrey Crossick and Roderick Floud, ed., The Power of the Past and Raphael Samuel and Gareth Stedman Jones, ed., Culture, Ideology and Politics.

Whether he is writing as an expert on fields like eighteenth to twentieth century Europe (especially Britain and France) or as a "participant observer" as in the essays in Revolutionaries, Hobsbawm always attracts a lively debate which in itself is a useful measure of his contributions to his discipline and his profession. For instance, his excursions into peasantry in Brazil (in Primitive Rebels) stirred up a strong reaction from a local PhD. student, Maria Isaura Pereira de Queiroz (1965). Undaunted and ready to accept criticism, Hobsbawm did some more research and published his findings in Bandits. His Karl Marx Memorial Lecture of 1978 was so thoughtprovoking that it stimulated a heated debate within the Left in Britain for a long time, the exchanges enough for the content of one book, The Forward March of Labour Halted. His most widely read book is claimed to be Age of Revolution (Thane et al., 1984). In summarising his achievements in the profession, Eugene Genovese claims that few historians, whether Marxists or not, can today claim not to have been influenced by Hobsbawm's works; "that he has advanced a Marxism at once living, coherent, undogmatic and with hegemonic prospects. His specific achievements on a breathtaking array of subjects ... have added up to a demonstration of the superiority of historical materialism as method and world view" (Thane et al., 1984). 


\section{III: DOING HISTORY}

Hobsbawm does not only write history, he writes about how to do history and, like everybody else, participates in making history. As a person, he is conscious of all three elements in doing the history of society (Thane et al., 1984). In the maiden issue of Past and Present he states that "... men are active and conscious makers of history and not merely passive victims and indices..." His active role in the development of the History of Marxism series illustrates how he contributes consciously to making history of the Marxist thought.

Hobsbawm's writings are full of guidelines as to what constitutes proper history, what is not and how to go about doing proper history. Faced with the question "What kind of history writing do we wish to encourage?" in Past and Present, he visits an Arab scholar of the fourteenth century who teaches history as:

... a record of human society or world civilisation; of the changes that take place in the nature of that society ... (and in general) $\ldots$ of all the transformations that society undergoes by its very nature (Hobsbawm et al., 1952).

At the time of the writing of this editorial, the other members of the group of young Marxist historians seriously believed - and as such admired him for his store of knowledge - that Hobsbawm had merely borrowed from a nonMarxist in order to pacify the non-Marxist members on the board of the new journal in order to ensure acceptance of the journal by the public (Hobsbawm et al., 1952). Contrary to this view, I think that Hobsbawm was actually influenced by Ibn Khaldun and he did not merely borrow a quotation to pacify anybody. In fact some of his comments indicate that he believed that if Khaldun had lived in the twentieth century, he would, probably have embraced the historical materialist method.

Hobsbawm's "passion for history" is a passion which seeks involvement in order to appreciate the continuities and transformations, to understand why one era is a pre-condition for the later eras. In Primitive Rebels, he argues that to understand the subject of study, documents alone would not be sufficient. There is the need for personal contact with the "people and the place" to experience the "feel" effect. He points out that though we have much information on medieval social movements like slave revolts, social heresies and sects etc., we cannot say we have a history of social movements since in the past these were treated largely as a series of episodes. Thus, for Hobsbawm, mere narration of events without any attempt to find relationships is anything but history. In Primitive Rebels, he claims he was preoccupied with analysing millenarianism as a force for mobilising the masses of peasants for revolutionary action (p. xi). This attitude of Hobsbawm to making history is reinforced in Labour's Turning Point where he talks about "...everyday problems of working-class organisation with a view to accelerating the pace of change." In this book, Hobsbawm attempts to "by-pass secondary history and return directly to the men and women of the period themselves." Consequently, he avoided material commonly available in libraries and went in for pamphlets, periodicals, newspapers, official and unofficial surveys and the mass of biographical literature (Hobsbawm, 1974).

A look at Hobsbawm's contribution to historical methodology would be incomplete without saying something about his preface to volume one of the History of Marxism because in this chapter, he undertakes a major construction of a specific history, Marxism. Since Marxism, the most practically influential school of theory in the history of the modern would, is both a method of interpreting and changing it, Hobsbawm contends that its history must be written accordingly. The territory to be covered in this history is indeed very wide because Marxist thinkers have expressed opinions on everything imaginable - from mathematics, through painting to sexual relations.

Hobsbawm would prefer to be regarded as a "historian of society" and this should explain why 
his subjects are so many. He is a scholar who cannot be compartmentalised, in terms of subject, in terms of period and in terms of geography. Even though he should be comfortable with Europe, especially Britain and France in the eighteenth, nineteenth and twentieth centuries, his geographical sweep extends throughout Europe, the Americas, the Islamic world, the Asias, Africa and even Australia. His wanderings have taken him into seventeenth century Europe knowing very well that he is not an expert of the period (Hobsbawm, 1973). This characteristic of Hobsbawm is also a characteristic of the history that he does. For him, history is more than social history and certainly wider that economic history (Hobsbawm, 1971). Thus whether he is discussing artisans (for instance, "Political shoemakers" or "the Tramping Artisan") the problem of the relation between agriculture and capitalist development ("Scottish Reformers of the $18^{\text {th }}$ Century and Capitalist Agriculture"); Pre-Capitalist Economic Formation, "Economic Fluctuations and Some Social Movements since 1800"; "Machine Breakers"; "Messiahs of Brazil" (peasants), The Jazz Scene; The Age of

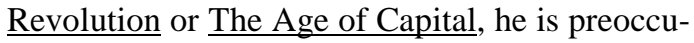
pied with one thing, society: how it can be interpreted with the view to changing it for the benefit of the "forgotten majority." In short, society is the subject of Eric Hobsbawm. It is also his overall theme and he employs the Marxist methodology to explain his society. Both man and method operate in global terms to have a macro view of the dialectics of society - thoroughness and identification with subject. Thus unlike Judith Fingard, Richard Rice cannot accuse Hobsbawm of writing the history of the "foc's1" from the "poop" (Rice, 1983).

\section{IV: SURVEY OF HOBSBAWM'S BOOKS}

The Age of Capital_was published in 1975 and it was Hobsbawm's tenth major publication. It was not his last. Thus the reason which encouraged me to select it rather that the other books should throw some light on the man's contributions to historiography. I should like to begin with the negative reasons, that is, why I did not select the other books.

\section{LABOURS TURNING POINT}

This was the first book published by Hobsbawm and it came out five years after the author had received his Master's degree and three years before his doctorate. It is a unique approach to doing history in that Hobsbawm decided to ignore material commonly available especially in libraries, and to draw on sources which would allow the "history makers" (Hobsbawm, 1974) to speak for themselves.

The general purpose of the book according to the author was an attempt to trace the relationship in changes within the labour movement (1880-1900) and the labour aristocrats; to demonstrate how varied the opinions were within the working class Left; to draw attention to the Irish element, the importance of local agitations, to trace the employers counterattack of the 1890 s and finally, to broaden the scope of the labour movement as available to students. In terms of the actual style of history done in this book, it is my opinion that Hobsbawm set out to make one statement, that is, "Taff Vale Made the Labour Party" (Hobsbawm, 1974). The whole text was then merely a sort of prolegomenon for that statement. He is able to achieve the effect in an unconventional way, as already indicated, by letting the real participants take us through the narrative. We are taken through the period of the old unions, through the radical phase of its development to the socialist phase. During this journey, we see how the discussions and debates progressed slowly through the Fabian era of gradualism up to the point when half a million workers saw the need for direct representation in Parliament (Hobsbawm, 1974). In short, when the "Taff Vale" Judgement was overturned in 1906, a legal organisation, the Labour Party had come into existence to look after the interests of labour in political decision making. It was the Taff Vale" Judgement therefore which opened the eyes of the Left to join forces in order to pursue the interests of labour better. This was the turning point. 
In an elaborate introduction, Hobsbawm had prepared us for the final verdict:

... The strength of socialism at the time lay in its critique of capitalism, its weakness in its isolation from the actual mass movement and its permeation by young intellectuals uninterested in the workers' power, like the youthful MacDonald (No. 54) ... The great feature of the day, however, which brought the more abstract socialists into touch with the organised workers themselves was the debate forced on both by the realties of the period: the problem of trade unions and the state (Hobsbawm, 1974).

The force of this style is apparent in No. 47, for instance, where the reproduction of the statement on the "Mission of the Fabians" tells us graphically what alternative forms of thinking were also developing in the period. This thinking was in sharp contrast with the Marxist line of thought and the contempt of Hobsbawm shows in his comments prior to No. 48. Secondly, earlier on in No. 35, his critique of the works of H.M. Hyndman, "What is Wrong with Capitalism?" had already placed the Fabians in perspective for the benefit of the reader. It was clear at this early stage that Hobsbawm wanted a quick realisation of the "heaven on earth" for the working class (Hobsbawm, 1974).

There are three reasons why I am not doing a more detailed critique of this book. The first is that the book was completed when the author was yet to gain extensive experience in his profession. Secondly, the theme of the book is too restricted to fit into the more general one I propose to employ. Finally, and following from the second, I would like to look at a book which while having a particular focus also has a global reach.

\section{PRIMITIVE REBELS AND BANDITS}

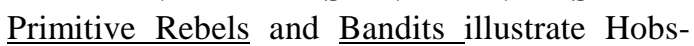
bawm's contribution to historical method from the view point of the subject of study. In these books Hobsbawm complains that: “...bandits and highwaymen preoccupy the police, but they ought to preoccupy the social historian ..." I am bypassing them because the territory covered is not global enough.

\section{PRE-CAPITALIST ECONOMIC FOUNDATION}

Perhaps the useful contribution this book makes to historiography is that in the elaborate introduction, Hobsbawm demonstrates his admiration and acceptance of the superiority of the Marxist method of historical analysis: that historical materialism has inspired a great deal of valuable historical work. Beyond this, there is not much ground to attract a critique. Like all edited books, it cannot be properly called a work of history, as such.

\section{REVOLUTIONARIES}

This book is largely a collection of essays and reviews of some books. Thus even though summary histories are attempted here, it cannot serve as an appropriate material for judging the historiographical contribution of the author. He himself classifies the contents as belonging to his "tourist views."

\section{THE FORWARD MARCH OF LABOUR HALTED}

Like Revolutionaries, this book cannot be described as a history. It is a lecture; a series of reactions to that lecture; and an interview of Hobsbawm, all combined into one book. It cannot be a text for the extended critique we wish to undertake here. In this lecture, however, Hobsbawm demonstrates the alert observer of social developments which he is. He makes the controversial claim, supported with sound argument that the advance of labour which he wrote about in Labour's Turning Point and which Engels made a prediction on, had come to a halt, thirty years ago. He points out that the working class had generally become better off but that there is another group of disproportionately underprivileged in British society, the non working class poor. This lecture 
demonstrates that even though Hobsbawm has written extensively about peasants, artisans, labourers and the workers, his preoccupation is with the non-privileged in society. Perhaps, this is one explanation why his histories are so appealing to all concerned with social justice.

CAPTAIN SWING, AGE OF REVOLUTION, INDUSTRY AND EMPIRE AND AGE OF CAPITAL

These four books are all well-written histories and as such merit attention equally for special study. However, the first is a joint-project with George Rude. Industry and Empire is centred on Britain. Age of Revolution has the same style as Age of Capital; in fact it precedes the latter in a History of Civilisation series. Consequently, there are repetitions of material covered in $\underline{\text { Age }}$ of Revolution in Age of Capital. For this reason, I do not wish to look at them together. I have elected to write a critique on the latter because whilst the book is centred on Europe it reaches out to the rest of the world. And the author calls it a genuine "world history". It is also an illustration of Hobsbawm's history of society.

\section{V: AGE OF CAPITAL}

In this book, Hobsbawm sets out to write the history of society, society understood as including what has been for many historians, the forgotten majority. However, unlike many of his earlier histories, the territory covered in this volume is very extensive. By the definition given to world history here, histories written of the world before 1848 are not regarded by the author as world history but rather as mere summations of the various parts of the globe. Thus for Hobsbawm, the first precondition for doing history must be the existence of a complete unit or system. A system implies the existence of composite parts. A good system may then be defined as the one with all its component parts functioning well. Any solution to a malfunctioning component of a system has to be in relation to the whole system. It cannot be an isolated attention as all parts of the system require to be in agree- ment all the time. This is a good illustration of Hobsbawm's method. Pathological attentions are not acceptable here. For a problem with one part of the system means that the whole system is sick and it is, therefore, the whole system which requires attention and not aspects of it. Such a system would be affected by both exogenous and endogenous factors, that is, transformations in society by its very nature. These methodological traits are brought to bear on the history of world society undertaken by Hobsbawm in Age of Capital.

The period selected for study is located in Europe. However, developments in Europe came to involve the whole world. This is industrial capitalism which matured in Europe between 1848 and 1875 and expanded to engulf the whole world thus transforming it into a single economy. Henceforth, the globe ceased to be a mere "geographical expression". Rather it became an operational reality and, according to Hobsbawm, history now became "world history".

Integration of any society can be done form three principal angles: economic, political and sociocultural. By 1848, the last two were remote questions. And while there were contacts between different peoples and different places on the globe, it would be inappropriate so speak of one world unit. However, after 1848 economic aggression from Europe made it possible for production to be done on a world basis; raw materials were carted from certain regions to be transformed into finished products in Europe. Secondly, economic decisions taken in Europe tended to have some impact across the world. These are the issues discussed in Age of Capital which made capital supreme and the first employer round the world. Trade became international and between 1850 and 1870, it increased by 260 percent. In part II of the book, we are told that anything saleable was sold, including goods which met with resistance from the receiving countries. An example was opium exported from British India to China. Again by 1875 , one billion dollars had been invested abroad. Also between

108 Journal of Science and Technology, Vol. 28, No. 2, August, 2008 
1850 and 1880, French foreign investments increased ten times. This is capitalism which is defined as buying in the cheapest market and selling in the most expensive, in the spirit of competition to realise the maximum profits. Long-term deflation, defined as pressure on margins of profit, tends to harm business expansion. On the other hand, inflation raises profit margins and in so doing encourages business. The period $1848-75$ is then described basically as an inflationary interlude in a deflationary century. Hence the rapid economic expansion, progress which was celebrated by the international trade fair (Crystal Palace, 1851; Paris, 1855; Philadelphia Centennial, 1876). Two other factors explain why economic integration was possible. The first is the railway, the steamer and the telegraph. These were the communication media for integrating the world into a single economy and hence a single history, Secondly, the adventurism of the new middle class entrepreneurs is also cited. Hobsbawm, for instance, describes Thomas Brassey as a man who could employ 80,000 men on five continents. The achievements of the Saint-Simonian Sect of adventurers is also noted. One such adventurer, Ferdinand de Lesseps built the Suez Canal and started work on the Panama Canal. Another P.F. Talabot constructed, among others, the railways of SouthEastern France, the Marseilles docks and the Hungarian railways. Such men, we are told, thought in terms of continents and oceans. For them, the world was a single unit bound together with rails of iron and steam engines.

Various techniques for dong a history of society also show up in the Age of Capital. First, writing the history of the majority in the society for Hobsbawm, implied the necessity to play down "high politics", great names, war diplomacy, details of constitutional legislation, or avoid them altogether in order to give the common people some prominence. Thus the great names in European politics of the period are quickly introduced and then dismissed. Bismarck is presented to us "... as a deeply reactionary coun- try noble man from Prussia ...", Napoleon III is described as an "imitation emperor" "who found the cloak of his great uncle uncomfortable to wear". During these introductions, the politicians from Britain are not even mentioned by name. They were simply described as a "succession of aristocratic landowners". Secondly, in writing a history of society, it is Hobsbawm's conviction that a simple language is a moral obligation.

In the Preface, Hobsbawm points out that if historians have to justify the resources that society devotes to their subject, then they should not write exclusively for other historians. Consequently, Hobsbawm's language in Age of Capital is simple, enjoyable and readable. This palatability is explained by the efficiency and beauty of the prose and a literary style which makes the reader enjoy not only what is being said but how it is being said. One passage from the Introduction will illustrate the point:

... The most obvious drama of the period was economic and technological; the iron pouring in millions of tons over the world, snaking in ribbons of railways across the continents, the submarine cables crossing the Atlantic, the construction of the Suez Canal, the great cities like Chicago stamped out of the virgin soil of the American midwest, the huge streams of migrants. It was the drama of European and North American power, with the world at its feet. But those who exploited this conquered world were ... sober men in sober clothes, spreading respectability and a sentiment of racial superiority together with gasworks, railway lines and loans...(p. 4)

The power of the imagery is evident and the passage can easily be mistaken for one from a novel. Words like "stamping out" cities when combined with "virgin soils" conjure the image of the speed with which America was urbanised in the name of industrialisation and betray the author's admiration for the achievements of those middle class pioneers who after all were only "sober men in 
sober clothes". Such linguistic ability runs throughout the course of the book and makes the history very readable. It also enables the author to summarise historical data with casual ease. For instance, in rounding off the achievements of the 1848 revolutions and preparing the way for the main chapters on economic development he observes: "The revolutions of 1848 made it clear that the middle classes, liberalism, political democracy, nationalism, even the working classes, were henceforth permanent features of the political landscape".

This attitude of consciously writing beautiful prose, sometimes, gets him into trouble as he loses control over the facts. For instance, words and phrases of uncertainty such as "whatever" (p. 78) and "whether is was true" (p. 110) are employed on numerous occasions and sometimes quite unnecessarily. Thus on page 110 he could simply have stated a fact rather than wonder whether workers of the world really have a country because he had expressed an interpretation of it earlier on p. 93. His generalisation about Italian languages makes Mazzini look like a liar, and his habit of employing certain funny expressions do not add to the efficiency or beauty of his prose: in quick succession we are confronted with the expression "talking dialect" (p. 86), "talking language" (p. 87) and "talking idioms" (p. 89). These words, however, carry the advantage of reminding us of the people whose history is being written, that is, the people of the countryside, the dialect speaking majority.

Periodisation should be very important in writing the history of world society for by its very nature the subject is already very extensive and periodisation is a method of focusing attention. Secondly, it makes comparison much easier and since Hobsbawm's histories are interpretation of the present in the light of the past, a clearly stated period becomes indispensable. Accordingly in Age of Capital Hobsbawm is very conscious of his period to the point that he displays some uncertainty both at the beginning and at the end of the book as to the exact year to open and close the discussion.

One problem which a person doing a history of the world is likely to encounter is the vastness of the subject matter to comprehend. This makes disclosure of all sources used very critical in maintaining the credibility of the historian involved since he is not likely to be an expert in all fields and disciplines to be spanned. Fortunately, Hobsbawm does not have this problem. He makes a genuine effort to record all references and influences and relies heavily on footnotes and endnotes to throw more light on the meaning and source of the material. In Age of Capital, there is a clear continuation of this practice. There is also a bibliographic essay at the end to guide interested persons to further reading on the subject.

\section{VI: STRUCTURE}

There are two parts of the book: Developments and Results. The part on Development deals with economic developments while the part on Results is principally concerned with social and cultural change corresponding to the economic change. The division is interesting for several reasons. The structure first suggests the imminence of change, that is, whatever subject is going to be studied will be a dynamic subject. Both exogenous and endogenous factors come to play very easily in this structure. Exogenous factors are the factors external to the system in question which affect the process of change. Endogenous factors are internal developments which make further change necessary. Both in terms of time and space, the structure "Developments and Results" defines a complete entity, a total system and as such this structure is the first real contribution of Hobsbawm's towards a study of a dynamic history of the world. The reason is that it at once enables an interpretation of the present in the light of the past and affords an explanation of the world with the view to changing it. Secondly, it is one practical model for using the Marxist Methodology for studying of societies. One basic tenet of Marxist teaching is that the economic 
element is the primary motivation factor in explaining change in the world. In Marxian parlance, it is the substructure which determines the superstructure. If the section of Development is taken as a gradual definition or unfolding of the substructure of a bourgeois society, then the Results section defines the nature of the corresponding social and cultural apparatus of bourgeois society. This latter one is the superstructure. It is in the superstructure of society that the contradictions in society mature and lead to an undermining of the substructure which is a basic Marxist explanation of change.

The structure described above is not found in all of Hobsbawm's histories, but it is the same structure employed in Age of Revolution. Just as in Age of Capital, certain changes in the economic foundations of European society led to the emergence of new social realties. These were the realities which made the 1848 revolutions inevitable. While there are advantages to this style, there are also attendant problems. For instance, it is this regimentation which, perhaps, accounts for the appearance of the chapter on "Wars and Conflicts" in between Chapters 3 and 5 in the Age of Capital, an arrangement which does not help the progress of the global theme then developing in any way. I should point out that it is not only the parts which are similar the topics under each part are also similar. Thus both parts on Results begin with a discussion of land. Here it appears that, like the Physiocrats, Hobsbawm considers land the sole source of wealth and as such its revolutionary transformation must be the necessary pre-condition and consequences of bourgeois society (Age of

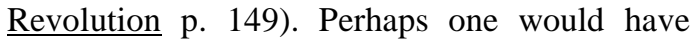
expected Hobsbawm to have looked at the land question on the subject of Development since that is a more obvious index of measuring economic change. In any event, the 1848 revolution came to an end with two discoveries by the rising new class: the first was that revolution was dangerous and second that a substantial portion of their demands could be met by the aristocratic class without it. According to Hobsbawm, once this realisation was reached, the bourgeoisie ceased to be a revolutionary force. The hegemony of capital had begun.

In Part II of the book, Hobsbawm begins to look at the hegemony of capital, especially its economic and political basis. The "Great Boom", the subject of the first chapter, was a period of rapid economic expansion, so rapid that “... politics per se went into hibernation ..." (p. 31). The profit motivation led to several technological and industrial advances and soon capital came to bend politics to its needs. The details of the industrial and technological achievements are discussed on pages $32-45$. However, the railway, the steamer and the telegraph, we are told, became the communication media for integrating the world into a single economy, hence a single history.

Chapter three discusses the process of world economic integration. The arguments in the first few pages of this chapter are unconvincing. For instance, he appears to have a problem of how the explorations succeeded in linking the external territories to the world market and thinks it is a complex question. And yet it was this same man, a moment ago, who was proposing the new world history and defining early contacts with foreign markets out of such history. Part of his problem, I think, is his refusal to give credit to Lenin's thesis on the subject. Lenin had demonstrated that the highest expression of capital's penetration into the external markets was imperialism. Another could be his romantic flirtation and apparent reliance on the testimonies of British Foreign Office personnel. Not surprisingly, his exposition on the civilising mission and the white man's burden is quite weak. The employment of the word "underdeveloped" to describe Cuba of 1845 is careless. His admiration for the rising middle class entrepreneur is evidently demonstrated from page 56 onwards. The names and achievements of men like Thomas Brassey, de Lesseps and P.L. Talabot are then recounted.

Thus after a disastrous performance on the question of the transition to colonialism, Hobsbawm finds 
his wit once more: "For such men human destiny, history and profit were one and the same thing." We are then introduced to the beginning of the era of international contracts and big business. In the following pages we are informed of the progress on other international forms of communication, that is, shipping, telegraph and under water cables. The chapter ends with two reminders: first that the confidence of these entrepreneurs rested on insecure foundations and second, that the unity of the world implied divisions. The reason for this, we are told, is that the capitalist world was one of rival "national economies".

Professor Ashworth complains about exaggerated contrasts because of the manner in which the last chapter was closed and the way this one is opened. I do not find this particular criticism worrying. What I do not like about the chapter is what is contained in here: wars and conflicts in Europe, mainly. The only messages we get here are that first, there were so many wars during the period that it makes it look like a rather warlike interlude in what was otherwise an unusually peaceful century between 1815 and 1914. Second, that despite these conflicts, the era of liberal triumph had been stable and that it would not be so after 1875 . I do not, however, see any contribution to the development of the trend of thought that this chapter presents, by placing it in between the ones on economic transformation and the development of nationalism. It appears the structure in Age of Revolution is being rigidly adhered to here.

Chapter five (Building Nations) and Chapter six (Forces of Democracy) both dwell on Europe, largely. In the case of the former, in so far as integration of the world into a single unit is concerned, I find it useful. A clear and rewarding case is made for the Irish Republican Army, especially, how that problem came into being. Unlike Genovese, I do not find the discussion on nationalism particularly first rate. The chapter on democracy is understandable in that it was here that the fight for modern notions of democracy originated. There is also a good account of the Internationals.
The next two chapters are named "Losers" and "Winners." After the break to discuss purely European concerns, we return to the discussion of the one world economy and its implications. The whole of the Third World is described as losers with some justification because these countries entered the new system as auxiliaries. The Egyptian economy, for instance, was turned into an agricultural export economy supplying the capitalist world with wheat and especially cotton in return for no advantages, whatsoever, but rather for poverty, starvation, the disruption of their ancient ways. This is a chapter where the weaknesses in the author's knowledge of the African continent are demonstrated. A certain reluctance is discerned in him when he opens the discussion on different types of colonies -- a matter he could have pursued to profit. Countries of European stock are treated as winners together with Japan.

In the final chapter of Part II, Hobsbawm looks briefly at the alternatives to capitalism as a system of thought and development. Those mentioned include the anarchism of Proudhon and Bakunin and Russian populism. The main revolution during the period we are told did not take place in Europe but in far away Taiping. The chapter ends with a brief reference to the Paris Commune which is described as having frightened the wits out of the bourgeois order.

In the Third Part of the book, the author is very much at home because he is discussing here, issues which are so near his heart, the social consequences and the context of social change. On the chapter on land, agrarian matters dominate the discussion. We are told that a growing part of agriculture came to be subjected under the industrial world economy resulting in major "flight from the land". The dynamic element in agricultural development was demand. This was explained by the growing food needs of the urban industrialised centres which also competed with agriculture for the same labour. As a result of the boom years, it is said that the capacity of the new capitalist economy to give employment caught up with its capacity to multiply production. Thus during the period, world agriculture was a

112 Journal of Science and Technology, Vol. 28, No. 2, August, 2008 
dual agriculture: one dominated the capitalist market and using increasingly mechanical devices to assist in production and another which remained largely independent of it.

In general, modernisation led to migrations when people were uprooted from their traditional homes or countries. This is the subject of chapter 11. This mobile population does not only explain how countries like America came to be populated so quickly, it also shows the beginnings of the high mobility of people within Europe itself.

Chapter 12 is another very good chapter. The author is a master of the subject matter, i.e., industrialisation and its social effects on the poor and the working class.

In the chapter on the bourgeoisie, a vivid picture is painted of a new class, a nouveau-riche which is so unsure of itself that its life, from beginning to end, is presented as one of pretence. This is the only chapter, so far, which vindicates the author's claim in the third chapter that the bourgeois confidence rested on insecure foundations.

The chapter on Science, Religion and Ideology is not exactly original. There is a summary of the achievements in science during the period. There is also a bold attempt to explain the racism of the age.

Chapter 15 dwells at length on the contributions of the period by way of the arts. Here again as in the preceding one, the chapter is largely a summary of achievements. Great names like Charles Dickens, George Elliot, Alfred Lord Tennyson, Victor Hugo, Emile Zola, Tolstoi, Dostoievsky, Turgenev, among others, are noted together with the contributions they made in their respected fields. The affluence of the era is also presented in its architecture, witness the Crystal Palace (1851), the Rotunda of Vienna Exhibition of 1873 and the much later Eifel Tower (1889). Other imposing structures of the period include the London Bridge (1862), St. Pancras, London (1868) and the Sudbahnof of Vienna (1869-73).

Two points made in this chapter which tie in with the overall theme of the book are: first, that the arts reflected the affluence and prosperity of the era and that the artist soon came to terms with the market. Thus by 1870 , Charles Dickens was reckoned to be making about $\$ 150,000$ annually and this placed him among the topmost rich of the era. Those artists who did not become wealthy in their time, did not lack respect, we are told. Secondly, the culture of the period "high culture" emerged with the bourgeois triumph and undermined traditional rural patterns of culture. This was achieved not so much through migration as by education. Once primary education was available to the masses, traditional culture invariably receded before the dominant culture of the literate. This is the author's presentation of the hegemony of the new elite in the cultural realm.

Hobsbawm concludes his study of the period on a pessimistic note for the bourgeoisie. He argues that the Great Depression of 1876-96 was an interlude. But he points out that the end of the period was marked by three spectacular events which sent shock waves throughout the bourgeois world. The first was German Unity with its ominous threats and vitality; the second was the Paris Commune of 1871 and the last was the great stock exchange crash of 1873. Whilst the second frightened the bourgeois out of their wits, the third, especially its sustained form, the Depression, opened an era of imminent revolution, we are told. And this was why the bourgeois was a little less self-confident as it entered the twentieth century. And this was also the reason, perhaps, why the age of revolution was not over.

\section{VII : CONCLUSION}

If the success of a professional is judged by the amount of work produced, the acceptance of such works and the impact of the personality of the said professional on his discipline, then Eric Hobsbawm is certainly a successful professional Marxist historian. And even though he himself chooses to play down his Marxist position and is known to have discarded many Marxist pieties, I would like to agree with Eugene Genovese that Hobsbawm has succeeded in advancing a Marxism at once living, 
coherent and undogmatic and that in doing history of common people, labourers, artisans, as well as world history, he has demonstrated the superiority of historical materialism as a method and a world view. The structure used in Age of Capital, in my opinion, is a practical application of this method for doing the history of world society.

\section{REFERENCES}

Academic Who's Who, (1975). University Teachers in the British Isles in the Arts, Education and Social Sciences. London: Adam and Charles Black.

Ashworth, W. (1969). Industry and Empire. Economic History Review, 22: 140-41.

Ashworth, W. (1976). The Age of Capital. Economic History Review, 29: 528-29.

Brailsford, H.N. (1949) The Life and Works of J. A. Hobson. Economic History Review, 2: 107.

Braudel, F. (1968). La Mediterranee et le Monde Mediterranean a l'epoque de Phillipe II" (New Edition). Past and Present, 39: 173-74.

Bridbury, A.R. (1973). Historians and the Open Society. Economic History Review, 26: 721.

Checkland, S.G. (1965). The Rise of Industrial Society in England, 1815-1885. Economic History Review, 18: 650.

Cole, G.D.H. (1954-55). Attempts at General Union, 1818-1834. Economic History Review, 7: 118 .

de Queiroz, M.I.P. (1965). Messiahs in Brazil (critique of Primitive Rebels). Past and_Present, 31: 62-86.

Dewey, C. (1982). Peasants in History. Economic History Review, 35: 334-35.

Earle, E.M. (1951-52). Modern France: Problems of the Third and Fourth Republics. Economic History Review, 4: 258.

Follows, J.W. (1951-55). Antecedents of the International Labour Organisation. Economic History_Review, 4: 120.
Fussel, G.E. (1948-50). From Tolpruddle to TUC. Economic History Review, 1: 167.

Graus, Fr. (1963). Early Lives of Saints. Past and Present, 26: 4-5.

Harrison, B. (1967). Labouring Men: Studies in History of Labour. Economic History Review, 20: 178.

Hobsbawm, E.J. (1948-50). General Labour Unions, 1889-1914. Economic History Review, 1: 123.

Hobsbawm, E.J. (1950-51). The Tramping Artisan. Economic History Review, 3: 299.

Hobsbawm, E.J. (1952). The Machine Breakers. Past and Present, 1: 57-70.

Hobsbawm, E.J. (1952-53). Economic Fluctuations and Some Social Movements since 1800. Economic History Review, 5: 1.

Hobsbawm, E.J. (1954). The General Crisis of the European Economy in the 17th Century Part I. Past and Present, 5: 33-53.

Hobsbawm, E.J. (1954). The General Crisis of the European Economy in the 17th Century Part II. Past and Present, 6: 44-65.

Hobsbawm, E.J. (1957). 20th Century British Politics. Past and Present, 11: 100-8.

Hobsbawm, E.J. (1957-58). The British Standard of Living, 1789-1850. Economic History Review, 10: 46 .

Hobsbawm, E.J. (1960). Trevor Roper's 'General Crisis -- Contribution to Symposium. Past and Present, 18: 12-14.

Hobsbawm, E.J. (1962). Age of Revolution. London: Weidenfeld and Nicolson.

Hobsbawm, E.J. (1963). Anglo-American Historical Conference. Past and Present, 26: 4.

Hobsbawm, E.J. (1964). Karl Marx: Pre-Capitalist Economic Formation, ed. London: Lawrence and Nicolson.

Hobsbawm, E.J. (1966). Delio Cantimori - 19041966. Past and Present, 35: 157-58.

114 Journal of Science and Technology, Vol. 28, No. 2, August, 2008 
Hobsbawm, E.J. (1967). Trade Union History. Economic History Review, 20: 358-64.

Hobsbawm, E.J. (1968). Industry and Empire: An Economic History of Britain Since 1750. London: Weidenfeld and Nicolson.

Hobsbawm, E.J. (1969). Bandits. London: Weidenfeld and Nicolson.

Hobsbawm, E.J. (1971). From social history to the history of society. Daedalus, 100: 20-45.

Hobsbawm, E.J. (1973). Revolutionaries. London: Weidenfeld and Nicolson.

Hobsbawm, E.J. (1974). Labour's Turning Point (1800-1900). Sussex: The Harvester Press.

Hobsbawm, E.J. (1974). Peasant Land Occupations. Past and Present, 62: 120-52.

Hobsbawm, E.J. (1975). Age of Capital. London: Weidenfeld and Nicolson.

Hobsbawm, E.J. (1975). The Jazz Scene. Da Capo Press.

Hobsbawm, E.J. (1982). The History of Marxism I: Marxism in Marx's Day. Bloomington: Indiana University Press.

Hobsbawm, E.J. (1984). Worlds of Labour: Further Studies in the History of Labour. London: Weidenfeld and Nicolson.

Hobsbawm, E.J. and Baran, P.A. (1961). The Stages of Economic Growth. Kyklos, XIV(2): 234-42.

Hobsbawm, E.J. and Hartwell, R.M. (1964). The Standard of Living During the Industrial Revolution: A Discussion. Economic History Review, 16: 120.

Hobsbawm, E.J. and Ranger, T. (1983). The Invention of Tradition. Cambridge: Cambridge University Press.

Hobsbawm, E.J. and Rude, G. (1969). Captain Swing. London: Lawrence and Wishart.

Hobsbawm, E.J. and Scott J.W. (1980). Political Shoemakers. Past and Present, 89: 86-114.

Hobsbawm, E.J., Gill, K. Benn, T. (1981). The
Forward March of Labour Halted? (ed. Martin Jacques and Francis Mulhern). London: NLB in association with Marxism Today.

Hobsbawm, E.J., Hill, C. And Hilton, R.H. (1983). Past and Present: Origins and Early Years. Past and Present, 100: 3-14.

Hobsbawm, E.J., Kula, W., Mitra, A., Raj, K.N. and Sachs, I. (1980). Peasants in History: Essays in Honour of Daniel Thorner. Calcutta: Oxford University Press.

Howe, E. and Child, J. (1954-55). The London Society of Bookbinders. Economic History Review, 7: 120.

Jones, E.L. (1969). Captain Swing. Economic History Review, 22: 354-55.

Katona, I. (1963). Cooperative Work Groups. Past and Present, 26: 5.

Lefebvre, G. (1974). The Great Fear of 1789. Economic History Review, 27: 507.

Merriman, J. (1979). The Agony of the Republic: The Repression of the Left in Revolutionary France, 1848-1851. Economic History Review, 32: $621-22$.

Nettl, J.P. (1967). Rosa Luxembourg. Economic History Review, 20: 412.

Nkrumah, K. (1970). Conciencism: Philosophy and Ideology for Decolonisation and Development with Particular Reference to the African Revolution (Reviewed edition), New York: Monthly Review Press.

Pollard, S. (1960-61). A History of Labour in Sheffield. Economic History Review, 13: 127.

Rice, R. (1983). Sailortown: Theory and Method in Ordinary People's History. Acadiensis, XIII(1): 154-68.

Russell, R. C. (1957-58). The 'Revolt of the Field' in Linconshire. Economic History Review, 10: 494.

Samuel, R. and Jones, G.S. (1982). Culture, Ideology and Politics. London: Routledge and Kegan Paul. 
Saul, S.B. (1978). Europe: 1850-1940. Economic History Review, 31: 692.

Thane, P., Crossick, G. and Floud, R. (1984). The Power of the Past: Essays for Eric Hobsbawm. Cambridge: Cambridge University Press.

Winter, J. (1984). The Working Class in British History. Economic History Review, 37: 143. 